\title{
EuGH: Anhängige Rechtssachen/CJEU: Pending Cases
}

\author{
Stephan Keiler
}

(C) Springer-Verlag 2012

\section{Fernabsatz/Distance Selling}

Rs/Case C-49/11 Content Services/Bundesarbeitskammer

Erfüllung der Informationspflicht beim Fernabsatzgeschäft mittels Hyperlink

Fulfilment of duty to provide information on selling by means of a hyperlink

Vorgelegt von/referred by: Oberlandesgericht Wien (Austria)

Vorlagefrage:

Genügt es dem Erfordernis von Art 5 Abs 1 FernabsatzRL 97/7/EG, wonach ein Verbraucher die Bestätigung der dort genannten Informationen auf einem für ihn verfügbaren dauerhaften Datenträger erhalten muss, soweit ihm diese Informationen nicht bereits bei Vertragsabschluss auf einem für ihn verfügbaren dauerhaften Datenträger erteilt wurden, wenn dem Verbraucher diese Informationen durch einen Hyperlink auf die Website des Unternehmers zur Verfügung gestellt werden, der sich in einem Text befindet, den der Verbraucher durch Setzung eines Häkchens als gelesen markieren muss, um ein Vertragsverhältnis eingehen zu können?

Question referred:

Is the requirement in Art 5 Para 1 Distance Selling Directive 97/7/EC to the effect that a consumer must receive confirmation of the information specified there in a durable

Ass-Prof Dr. Stephan Keiler, LL.M ( $ه)$

Universität Salzburg,

Kapitelgasse 5-7, 5020 Salzburg, Österreich

E-Mail: <stephan.keiler@sbg.ac.at>

Anm: Hervorhebungen vom Autor/remark: accentuations by the author. medium available and accessible to him, unless the information has already been given to him on conclusion of the contract in a durable medium available and accessible to him, satisfied, where that information is made available to the consumer by means of a hyperlink on the trader's website which is contained in a line of text that the consumer must mark as read by ticking a box in order to be able to enter into a contractual relationship?

\section{Unlautere Geschäftspraktiken/Unfair Commercial Prac- tices}

a. Rs/Case C-206/11 (Köck/Schutzverband gegen unlauteren Wettbewerb)

Bewilligungspflicht der Ankündigung eines Ausverkaufs Requirement of authorisation of the announcement of a clearance sale

Vorgelegt von/referred by: Oberster Gerichtshof (Austria)

Vorlagefrage:

Stehen Art 3 Abs 1 und Art 5 Abs 5 RL über unlautere Geschäftspraktiken 2005/29/EG oder andere Bestimmungen dieser RL einer nationalen Regelung entgegen, wonach die Ankündigung eines Ausverkaufs ohne Bewilligung der zuständigen Verwaltungsbehörde unzulässig und daher in einem gerichtlichen Verfahren zu untersagen ist, ohne dass das Gericht in diesem Verfahren den irreführenden, aggressiven oder sonst unlauteren Charakter dieser Geschäftspraktik prüfen müsste?

Question referred:

Do Art 3 Para 1 and Art 5 Para 5 Unfair Commercial Practices Directive 2005/29/EC or other provisions of 
that directive preclude a national provision under which the announcement of a clearance sale without the authorisation of the competent administrative authority is not permitted and for that reason must be prohibited in court proceedings, without it being necessary in those proceedings for the court to consider whether such a commercial practice is misleading, aggressive or otherwise unfair?

b. Rs/Case C-428/11 (Purely Creative ea/Office of Fair Trading)

Gewinnzusagen aus Sicht der $R L$ über unlautere Geschäftspraktiken

Prize notifications and the Unfair Commercial Practices Directive

Vorgelegt von/referred by: Court of Appeal [England \& Wales] (United Kingdom)

\section{Vorlagefragen:}

1. Ist Nr 31 Anhang I RL über unlautere Geschäftspraktiken 2005/29/EG dahin auszulegen, dass es einem Gewerbetreibenden verboten ist, Verbrauchern mitzuteilen, dass sie einen Preis oder einen sonstigen Vorteil gewonnen hätten, wenn der Verbraucher in Wirklichkeit in Bezug auf die Inanspruchnahme des Preises oder eines sonstigen Vorteils dazu angehalten wird, Kosten, einschließlich geringfügiger Kosten, zu übernehmen?

2. Für den Fall, dass der Gewerbetreibende dem Verbraucher für die Inanspruchnahme des Preises oder sonstigen Vorteils verschiedene Vorgehensweisen anbietet: Ist Nr 31 Anhang I verletzt, wenn jegliche Möglichkeit des Verbrauchers, eine Handlung in Bezug auf die Inanspruchnahme - nach welcher Vorgehensweise auch immer - vorzunehmen, von der Zahlung eines Betrags oder der Übernahme von Kosten, einschließlich geringfügiger Kosten, durch den Verbraucher abhängig gemacht wird?

3. Falls Nr 31 Anhang I nicht verletzt sein sollte, wenn die Vorgehensweise bei der Inanspruchnahme des Preises oder sonstigen Vorteils für den Verbraucher bloß mit geringfügigen Kosten verbunden ist: Wie soll das nationale Gericht feststellen, ob solche Kosten geringfügig sind? Müssen solche Kosten insbesondere in vollem Umfang dafür anfallen:

dass die Werbefirma den Verbraucher als Gewinner des Preises identifizieren kann und/oder dass der Verbraucher den Preis in Besitz nehmen kann und/oder

dass der Verbraucher das Erlebnis genießen kann, das als Preis beschrieben wird?

4. Folgt aus dem Ausdruck „fälschlicher Eindruck“ in $\mathrm{Nr}$ 31, dass zusätzlich zu dem Erfordernis, dass die Inanspruchnahme des Preises von der Zahlung eines Betrags oder der Übernahme von Kosten durch den Verbraucher abhängig gemacht wird, noch andere Kriterien erfüllt sein müssen, damit ein nationales Gericht einen Verstoß gegen die Bestimmungen der Nr 31 feststellen kann?

Wenn ja: Wie soll ein nationales Gericht feststellen, ob ein solcher ,fälschlicher Eindruck“ erweckt wurde? Soll das nationale Gericht bei der Entscheidung, ob ein „,fälschlicher Eindruck" erweckt wurde, insbesondere den relativen Wert des Preises verglichen mit den Kosten seiner Inanspruchnahme berücksichtigen? Wenn ja: Sollte dieser „relative Wert" ermittelt werden bezogen auf:

die Stückkosten, die der Werbefirma für die

Anschaffung des Preises erwachsen, oder dieStückkosten, die der Werbefirma für die Bereitstel-

lung des Preises für den Verbraucher erwachsen, oder den Wert des Preises aus Sicht des Verbrauchers im Hinblick auf den geschätzten „Marktwert“ eines zum Verkauf stehenden gleichwertigen Gegenstands?

Questions referred:

1. Does the banned practice set out in Para 31 Annex 1 to Unfair Commercial Practices Directive 2005/29/EC prohibit traders from informing consumers that they have won a prize or equivalent benefit when in fact the consumer is invited to incur any cost, including a de minimis cost, in relation to claiming the prize or equivalent benefit?

2 . If the trader offers the consumer a variety of possible methods of claiming the prize or equivalent benefit, is Para 31 Annex 1 breached if taking any action in relation to any of the methods of claiming is subject to the consumer incurring a cost, including a de minimis cost?

3. If Para 31 Annex 1 is not breached where the method of claiming involves the consumer in incurring de minimis costs only, how is the national court to judge whether such costs are de minimis? In particular, must such costs be wholly necessary:

in order for the promoter to identify the consumer as the winner of the prize, and/ or

for the consumer to take possession of the prize, and/ or for the consumer to enjoy the experience described as the prize?

4. Does the use of the words ,false impression" in Para 31 impose some requirement additional to the requirement that the consumer pays money or incurs a cost in relation to claiming the prize, in order for the national court to find that the provisions of Para 31 have been contravened?

If so, how is the national court to determine whether such a ,false impression" has been created? In particular, is the national court required to consider the relative value of the prize as compared with the cost of claiming it in deciding whether a ,false impression' has been created? If so, should that ,relative value' be assessed by reference to: 
the unit cost to the promoter in acquiring the prize; or to the unit cost to the promoter in providing the prize to the consumer; or

to the value that the consumer may attribute to the prize by reference to an assessment of the ,market value' of an equivalent item for purchase?

\section{Missbräuchliche Klauseln/Unfair Terms}

Rs/Case C-92/11 (RWE Vertrieb/Verbraucherzentrale NRW)

Preisänderungsklauseln in Gaslieferverträgen

Terms concerning price variations in gas supply contracts

Vorgelegt von/referred by: Bundesgerichtshof (Germany)

Vorlagefragen:

1. Ist Art 1 Abs 2 Klausel-RL 93/13/EWG dahin auszulegen, dass Vertragsklauseln über Preisänderungen in Gaslieferungsverträgen mit Verbrauchern, die außerhalb der allgemeinen Versorgungspflicht im Rahmen der allgemeinen Vertragsfreiheit beliefert werden (Sonderkunden), nicht den Bestimmungen der RL unterliegen, wenn in diesen Vertragsklausein die für Tarifkunden im Rahmen der allgemeinen Anschluss- und Versorgungspflicht geltenden gesetzlichen Regelungen unverändert in die Vertragsverhältnisse mit den Sonderkunden übernommen worden sind?

2. Sind - soweit anwendbar - Art 3 und 5 Klausel-RL iVm $\mathrm{Nr} 1$ lit $\mathrm{j}$ und $\mathrm{Nr} 2$ lit b S 2 Anhang zu Art 3 Abs 3 sowie Art 3 Abs 3 iVm Anhang A lit b und/oder lit c der Erdgasbinnenmarkt-RL 2003/55/EG dahin auszulegen, dass Vertragsklauseln über Preisänderungen in Erdgaslieferungsverträgen mit Sonderkunden den Anforderungen an eine klare und verständliche Abfassung und/oder an das erforderliche Maß an Transparenz genügen, wenn in ihnen Anlass, Voraussetzungen und Umfang einer Preisänderung zwar nicht wiedergegeben sind, jedoch sichergestellt ist, dass das Gasversorgungsunternehmen seinen Kunden jede Preiserhöhung mit angemessener Frist im Voraus mitteilt und den Kunden das Recht zusteht, sich durch Kündigung vom Vertrag zu lösen, wenn sie die ihnen mitgeteilten geänderten Bedingungen nicht akzeptieren wollen?

Questions referred:

1. Is Art 1 Para 2 Unfair Terms Directive 93/13/EEC to be interpreted as meaning that contractual terms concerning price variations in gas supply contracts with consumers who are to be supplied outside the general obligation to supply gas and on the basis of the general freedom of contract (special customers) are not subject to the provisions of the directive if, in those contractual terms, the statutory provisions which apply to standard-rate customers within the frame- work of the general obligation to provide a connection and supply gas are incorporated unchanged in the contractual relationships with special customers?

2. Are Art 3 and Art 5 Unfair Terms Directive - in so far as they are applicable - in conjunction with point 1 lit $\mathrm{j}$ and point 2 lit $b$ second sentence of the annex referred to in Art 3 Para 3 Directive, and Art 3 Para 3 in conjunction with lit $\mathrm{b}$ and/or lit $\mathrm{c}$ of Annex A Internal Market in Natural Gas Directive 2003/55/EC to be interpreted as meaning that contractual terms concerning price variations in natural-gas supply contracts with special customers meet the requirements for plain and intelligible wording and/or possess the requisite degree of transparency if, although the grounds, preconditions and scope of a change in price are not set out, it is nevertheless ensured that the gas supply company informs its customers of every price increase in good time in advance and those customers have the right to terminate the contract by way of notice if they do not wish to accept the amended conditions of which they have been informed?

\section{Pauschalreisen/Package Travel}

Rs/Case C-134/11 (Blödel-Pawlik/HanseMerkur)

Anwendbarkeit der Deckung aus Insolvenzabsicherung Refund for money paid in the case of insolvency hedging

Vorgelegt von/referred by: Landgericht Hamburg (Germany)

Vorlagefrage:

Ist Art 7 Pauschalreise-RL 90/314/EWG auch dann anzuwenden, wenn der Reiserveranstalter deshalb zahlungsunfähig wird, weil er die von den Reisenden vereinnahmten Gelder in von Anfang an betrügerischer Absicht in voller Höhe zweckfremd verwendet hat und eine Durchführung der Reise nie geplant war?

Does Art 7 Package Travel Directive 90/314/EEC also apply when the travel operator becomes insolvent because from the beginning with fraudulent intent it used all the money collected from the travellers for an improper purpose and it was never intended that the trip would be organised?

\section{Haustürgeschäfte/Doorstep Selling}

Rs/Case C-166/11 (González/Nationale Nederlanden Vida)

Anwendbarkeit der Haustürgeschäfte-RL auf Lebensversicherungsverträge

Applicability of the Doorstep Selling Directive to life assurance contracts

Vorgelegt von/referred by: Audiencia Provincial de Oviedo 
Vorlagefrage:

Ist Art 3 Abs 2 lit d Haustürgeschäfte-RL 85/577/EWG in dem Sinne eng auszulegen, dass von ihm ein außerhalb eines Geschäftsraums geschlossener Vertrag nicht erfasst ist, in dem eine Lebensversicherung gegen Zahlung einer monatlichen Prämie angeboten wird, die zu unterschiedlichen Teilen in festverzinsliche Anlagen, variabel verzinste Anlagen und Finanzanlageprodukte der Gesellschaft selbst investiert werden soll?

Question referred:

Must Art 3 Para 2 lit d Doorstep Selling Directive 85/577/ EEC be interpreted restrictively so as not to cover a contract, concluded away from business, under which life assurance is offered in return for payment of a monthly premium to be invested, in varying proportions, in fixed-rate investments, variable-rate investments and financial investment products of the company itself?

\section{Passagierrechte/Passengers'Rights}

\section{a. Rs/Case C-11/11 (Air France/Folkerts)}

Abflug- bzw Ankunftsverspätung als Voraussetzung und Berechnung der Verspätung bei mehrteiligen Flügen für Ausgleichsleistungen (gemäß der Entscheidung in den verb Rs C-430/07 und C-432/07 [Sturgeon/Condor; Böck and Lepuschitz/Air France])

Delay of departure or arrival as a requirement and calculation of delay in case of segmented flights for compensation (as decided in joined Cases C-430/07 and C-432/07 [Sturgeon/Condor; Böck and Lepuschitz/Air France])

Vorgelegt von/referred by: Bundesgerichtshof (Germany)

\section{Vorlagefragen:}

1. Steht dem Fluggast eine Ausgleichszahlung nach Art 7 Fluggastrechte-VO 261/2004/EG zu, wenn sich der Abflug um eine Zeitspanne verzögert hat, die unterhalb der in Art 6 Abs 1 VO definierten Grenzen liegt, die Ankunft am letzten Zielort aber mindestens drei Stunden nach der planmäßigen Ankunftszeit erfolgt?

2. Für den Fall, dass die erste Frage zu verneinen ist: Ist für die Frage, ob eine Verspätung im Sinne von Art 6 Abs 1 VO vorliegt, bei einem aus mehreren Teilstrecken zusammengesetzten Flug auf die einzelnen Teilstrecken oder auf die Entfernung zum letzten Zielort abzustellen?

Questions referred:

1. Does a passenger have a right to compensation under Art 7 Air Passengers' Rights Regulation 261/2004/EC in the case where departure was delayed for a period which is below the limits specified in Art 6 Para 1 of that regulation, but arrival at the final destination was at least three hours later than the scheduled arrival time?

2. If the first question is answered in the negative:

For the purpose of determining whether there was a delay, within the terms of Art 6 Para 1 Regulation, in the case of a flight consisting of several stages, should reference be made to the individual stages or to the distance to the final destination?

b. Case C-255/11 (Büsch und Siever/Ryanair)

Qualifikation der pauschalierten Ausgleichsleistungen in Abgrenzung zum MÜ (vgl Rs C-581/10)

Liquidated damages especially in regard to the scope of applicability of the MC (cf Case C-581/10)

Vorgelegt von/referred by: Amtsgericht Geldern (Germany)

Vorlagefragen:

1. Handelt es sich bei dem in Art 7 Fluggastrechte-VO 261/2004/EG geregelten Ausgleichsanspruch um einen Schadensersatzanspruch, der wegen Art 29 S 1 Montrealer Übereinkommens (MÜ) den Beschränkungen des MÜ unterliegt, wenn er wegen einer großen Verspätung des Fluges zuzuerkennen ist?

2. Ist der Ausgleichsanspruch des Art 7 VO nichtkompensatorisch im Sinne von Art 29 S 2 MÜ, soweit er die Schäden übersteigt, die dem Fluggast aufgrund der großen Verspätung entstanden sind? Schließt dies einen Ausgleichsanspruch zur Gänze aus oder entsteht dieser in Verspätungsfällen nur in Höhe des tatsächlich entstandenen Schadens?

Questions referred:

1. Does the right to compensation laid down in Art 7 Air Passengers' Rights Regulation 261/2004/EC constitute a claim for damages which is subject to the limits of liability set out in the Montreal Convention (MC), by virtue of Art 29 first sentence thereof, where it is to be granted because of a long delay of a flight?

2. Is the right to compensation under Art 7 Regulation noncompensatory within the meaning of the second sentence of Art $29 \mathrm{MC}$ in so far as it exceeds the damage incurred by the air passenger as a result of the long delay? Does this preclude a right to compensation entirely or does such a right arise in the event of delays only in the amount of the damage actually incurred?

\section{c. Rs/Case C-315/11 (van de Ven/KLM)}

Vereinbarkeit der analogen Anwendung der Regeln für Ausgleichsansprüche mit dem $M \ddot{U}$

Compatibility of analogous application of the rules on compensation with the MC 
Vorgelegt von/referred by: Rechtbank Breda (Netherlands)

Vorlagefragen:

1. Ist ein Ausgleichsanspruch iSv Art 7 FluggastrechteVO 261/2004/EG bei Verspätung in Anbetracht der Tatsache, dass Schadensersatzansprüche aus Vertrag, unerlaubter Handlung oder aus einem sonstigen Rechtsgrund nach Art 29 S 1 Übereinkommen von Montreal (MÜ) nur unter den Voraussetzungen und mit den Beschränkungen geltend gemacht werden können, die in diesem Übereinkommen vorgesehen sind, mit Art 29 letzter Satz MÜ vereinbar?

2. Sofern ein Ausgleichsanspruch im Sinne von Art 7 VO bei Verspätung nicht mit Art 29 MÜ vereinbar ist, gelten dann hinsichtlich des Zeitpunkts des Wirksamwerdens der Entscheidung des Gerichtshofs in Bezug auf die vorliegende Rs und/oder generell irgendwelche Einschränkungen?

Questions referred:

1. Is a right to compensation in case of delay, as described in Art 7 Air Passengers' Rights Regulation 261/2004/EC, consistent with the last sentence of Art 29 Montreal Convention (MC), given the fact that, according to the first sentence of Art $29 \mathrm{MC}$, actions for damages founded in contract, in tort or otherwise, can only be brought subject to the conditions and such limits of liability as are set out in MC?

2. If a right to compensation in case of delay, as described in Art 7 Regulation, is not consistent with Art 29 MC, are any limitations then imposed in respect of the moment when the ruling of the enters into effect as regards the present case and/or in general?

\section{d. Rs/Case C-321/11 (Rodríguez Cachafeiro ea/Iberia)}

Nichtbeförderung nach Verspätung auf einer vorangehenden Teilstrecke eines Fluges

Denied boarding after delay of an earlier flight included in the ticket

Vorgelegt von/referred by: Juzgado de lo Mercantil A Coruña

\section{Vorlagefrage:}

Ist der Begriff der Nichtbeförderung in Art 2 lit j iVm Art 3 Abs 2 und Art 4 Abs 3 Fluggastrechte-VO 261/2004/EG so auszulegen, dass er auch den Fall erfasst, dass das Luftfahrtunternehmen die Beförderung verweigert, weil es auf der ersten im Flugschein ausgewiesenen Teilstrecke zu einer von ihm zu vertretenden Verspätung gekommen ist und das Unternehmen in der irrigen Annahme, die Fluggäste würden den zweiten Flug nicht rechtzeitig erreichen, die Plätze mit anderen Fluggästen besetzt hat?
Question referred:

May the definition of , denied boarding " contained in Art 2 lit j, in conjunction with Art 3 Para 2 and Art 4 Para 3 Air Passengers' Rights Regulation 261/2004/EC be regarded as including a situation in which an airline refuses to allow boarding because the first flight included in the ticket is subject to a delay ascribable to the airline and the latter erroneously expects the passengers not to arrive in time to catch the second flight, and so allows their seats to be taken by other passengers?

\section{e. Rs/Case C-365/11 (Coelho dos Santos/TAP)}

Analoge Anwendung der Regeln über Ausgleichsleistungen auf einen Flug, der sich bei einer Zwischenlandung verspätet (aus Sicht der Entscheidung in den verb Rs C-430/07 and C-432/07 [Sturgeon/Condor; Böck and Lepuschitz/Air France])

Analogous application of rules regarding compensation to a flight delayed during a stopover (in the light of the decision in joined Cases C-430/07 and C-432/07 [Sturgeon/Condor; Böck and Lepuschitz/Air France])

Vorgelegt von/referred by: Tribunal de Pequena Instância Cível de Lisboa (Portugal)

Vorlagefrage:

Sind in der Folge des Urteils des Gerichtshofs vom 19.11.2009 (verb Rs C-402/07 und C-432/07), wonach die Art 5, 6 und 7 Fluggastrechte-VO 261/2004/EG dahin auszulegen sind, dass die Fluggäste verspäteter Flüge im Hinblick auf die Anwendung des Ausgleichsanspruchs den Fluggästen annullierter Flüge gleichgestellt werden können, wenn sie wegen eines verspäteten Fluges einen Zeitverlust von drei Stunden oder mehr erleiden, diese Artikel in derselben Weise im Hinblick auf den Fall eines Fluges auszulegen, der, nachdem er zur vorgesehenen Zeit gestartet war, sich am Flughafen der Zwischenlandung um drei Stunden und fünfundfünfzig Minuten verspätete, weil die betreffende Fluggesellschaft aus operationellen Gründen beschlossen hatte, das Flugzeug auszuwechseln, und sich herausstellte, dass die Maschine, die die vorherige ersetzen sollte, bereits vor der Zwischenlandung defekt war und eine technische Intervention benötigte, so dass der Flug mit den besagten drei Stunden und fünfundfünfzig Minuten Verspätung an seinen Bestimmungsort gelangte?

Question referred:

As a result of the judgment of the Court of 19.11.2009 joined Cases C-402/07 and C-432/07, in which it was held that Art 5, 6 and 7 Air Passengers' Rights Regulation 261/2004/EC must be interpreted as meaning that passengers whose flights are delayed may be treated, for the purposes of the application of the right to compensation, 
as passengers whose flights are cancelled where the time that they have lost due to the delayed flight is more than three hours, should the said articles be interpreted in the same way in the case of a flight that, having started on time at the place of departure, was delayed at the stop-over airport for three hours and fifty five minutes before taking off again because the airline, for operational reasons, decided to change equipment, where the equipment that replaced the previous equipment had already broken down prior to the stopover and needed a technical intervention, so that the flight arrived at the destination location with the said delay of three hours and fifty five minutes?

f. Rs/Case C-436/11 (Schüsslbauer/Iberia) and Rs/Case C-437/11 (Schauss/TAP)

Anspruch bei großer Ankunftsverspätung, aber keiner großen Abflugverspätung

Compensation in case of a long delay at departure but none at destination

Vorgelegt von/referred each by: Bundesgerichtshof (Germany)

Vorlagefrage:

Steht dem Fluggast eine Ausgleichszahlung nach Art 7 Fluggastrechte-VO 261/2004/EG zu, wenn sich der Abflug um eine Zeitspanne verzögert hat, die unterhalb der in Art 6 Abs 1 VO definierten Grenzen liegt, die Ankunft am letzten Zielort aber mindestens drei Stunden nach der planmäßigen Ankunftszeit erfolgt?

Question referred:

Does a passenger have a right to compensation under Art 7 Air Passengers' Rights Regulation 261/2004/EC in the case where departure was delayed for a period of time less than the limits specified in Art 6 Para 1 Regulation but arrival at the final destination was at least three hours later than the scheduled arrival time?

g. Rs/Case C-112/11 (ebookers.com/vzbv)

Anwendbarkeit transparenter Preisbildung und opt-in auch auf Zusatzleistungen Dritter

Applicability of transparent pricing and opt-in to additional services provided by third parties

Vorgelegt von/referred by: Oberlandesgericht Köln (Germany)

Vorlagefrage:

Erfasst die Bestimmung des Art 23 Abs 1 Luftverkehrsdienste-VO 1008/2008/EG, wonach fakultative Zusatzkosten auf klare, transparente und eindeutige Art und Weise am Beginn jedes Buchungsvorganges mitgeteilt werden und die Annahme der fakultativen Zusatzkosten durch den Kunden auf „Opt-in“Basis erfolgt, auch solche im Zusammenhang mit Flugreisen stehenden Kosten, die für Leistungen Dritter (hier: den Anbieter einer Reiserücktrittsversicherung) anfallen und von dem Vermittler der Flugreise in einem Gesamtpreis gemeinsam mit dem Flugpreis von dem Fluggast erhoben werden?

Question referred:

Does Art 23 Para 1 Air Services Regulation 1008/2008/EC according to which optional price supplements are to be communicated in a clear, transparent and unambiguous way at the start of any booking process and are to be accepted by the customer on an opt-in basis, also apply to costs connected with air travel arising from services provided by third parties (in this case, an insurer offering travel cancellation insurance) and which are charged to the air traveller by the company organising the air travel together with the air fare as part of a total price?

h. Rs/Case C-136/11 (Westbahn Management/ÖBB Infrastruktur)

Pflicht zur Bekanntgabe von Verspätungen und Ausfällen von Zügen generell und Weitergabe dieser Informationen auch an andere Betreiber

Duty to inform about delay and cancellations of trains in general and passing this information on to other providers

Vorgelegt von/referred by: Schienen-Control Kommission Wien (Austria)

Vorlagefragen:

1. Ist Art 8 Abs 2 iVm Anhang II Teil II Eisenbahn-Fahrgastrechte-VO 1371/2007/EG dahin auszulegen, dass die Information über die wichtigsten Anschlussverbindungen neben den fahrplanmäßigen Abfahrtszeiten auch die Bekanntgabe von Verspätungen oder Ausfällen dieser Anschlusszüge umfassen muss?

2. Wenn Frage 1 bejaht wird:

Ist Art $5 \mathrm{iVm}$ Anhang II Eisenbahninfrastruktur-RL 2001/14/EG im Lichte von Art 8 Abs 2 iVm Anhang II Teil II VO dahin auszulegen, dass der Infrastrukturbetreiber verpflichtet ist, den Eisenbahnunternehmen in diskriminierungsfreier Weise Echtzeitdaten von Zügen anderer Eisenbahnunternehmen zur Verfügung zu stellen, sofern es sich bei diesen Zügen um die wichtigsten Anschlussverbindungen im Sinne des Anhang II Teil II VO handelt?

Questions referred:

1. Is Art 8 Para 2 in conjunction with Annex II, Part II Train Passengers' Rights Regulation 1371/2007/EC to be inter- 
preted as meaning that information on main connecting services must include, in addition to scheduled departure times, notification of delays to or cancellations of those connecting services?

2. If the answer to Question 1 is in the affirmative: is Art 5 in conjunction with Annex II Railway Infrastructure Directive 2001/14/EC to be interpreted, in the light of Art 8 Para 2 in conjunction with Annex II Part II Regulation as meaning that the infrastructure manager is under an obligation to make real-time data on other railway undertakings' trains available to railway undertakings in a non-discriminatory manner, in so far as those trains constitute main connecting services within the meaning of Annex II Part II Regulation?

VII. Internationale Zuständigkeit/International Jurisdiction

\section{a. Rs/Case: C-190/11 (Mühlleitner/Yusufi)}

Verbrauchergerichtsstand (anschließend an die Entscheidung in den verb Rs C-585/08 und C-144/09 [Pammer/ Schlüter und Alpenhof/Heller])

Jurisdiction over consumer contracts (following the decision in joined Cases C-585/08 and C-144/09 [Pammer/Schlüter and Alpenhof/Heller])

Vorgelegt von/referred by: Oberster Gerichtshof (Austria)

Vorlagefrage:

Setzt die Anwendung von Art 15 Abs 1 lit c Brüssel I-VO 44/2001/EG voraus, dass der Vertrag zwischen Verbraucher und Unternehmer im Fernabsatz geschlossen wurde?

Question referred:

Does the application of Art 15 Para 1 lit c Brussels I

Regulation 44/2001/EC presume that the contract between the consumer and the professional was concluded via distance-selling?

b. C-419/11 (Česká spořitelna/Feichtner)

Anwendungsbereich des Verbrauchergerichtsstandes für Wechselsachen
Scope of applicability of jurisdiction over consumers contracts regarding promissory notes

Vorgelegt von/referred by: Městský soud v Praze (Czech Republic)

Vorlagefragen:

1. Kann die Wendung ,Vertrag oder Ansprüche aus einem Vertrag, den eine Person (...) zu einem Zweck geschlossen hat, der nicht der beruflichen oder gewerblichen Tätigkeit dieser Person zugerechnet werden kann" in Art 15 Abs 1 Brüssel I-VO 44/2001/EG dahin ausgelegt werden, dass darunter auch Ansprüche aus einem bei seiner Begebung unvollständigen Wechsel fallen, die der Zahlungsberechtigte gegen den Wechselbürgen des Wechselausstellers geltend macht?

2. Kann unabhängig davon, ob die erste Frage zu bejahen oder zu verneinen ist, die Wendung ,Vertrag oder Ansprüche aus einem Vertrag“ in Art 5 Nr 1 lit a Brüssel I-VO 44/2001/EG dahin ausgelegt werden, dass darunter bei Berücksichtigung allein des Urkundeninhalts als solchem auch Ansprüche aus einem bei seiner Begebung unvollständigen Wechsel fallen, die der Zahlungsberechtigte gegen den Wechselbürgen des Wechselausstellers geltend macht?

Questions referred:

1. May the concept of matters concerning a contract concluded by a consumer for a purpose which can be regarded as being outside his trade or profession in Art 15 Para 1 Brussels I Regulation 44/2001/EC be interpreted as extending also to claims under a promissory note issued in incomplete form brought by the payee against the giver of the aval for the maker of the note?

2. Whether the answer to the first question is affirmative or negative, may the concept of claims relating to a contract in Art 5 Para 1 lit a Brussels I Regulation 44/2001/EC be interpreted in such a way that, having regard exclusively to the content of the document as such, it extends also to claims under a promissory note issued in incomplete form brought by the payee against the giver of the aval for the maker of the note? 